\title{
THE EFFECT OF THE FINANCIAL RATIOS ON THE SHARE PRICE OF INSURANCE COMPANIES LISTED IN THE IRAQI STOCK EXCHANGE MARKET USING MULTIPLE REGRESSION ANALYSIS APPLIED RESEARCH IN THE IRAQI STOCK EXCHANGE MARKET
}

\author{
Othman Abdul Qadir Hama Amin \\ Sulaimani Polytechnic University Kurdistan Region, Iraq \\ Othman.amin@spu.edu.iq
}

\begin{abstract}
This research aims to identify the most important financial ratios affecting the share price of insurance companies listed in the Iraqi Stock Exchange Market (ISEM) during the period 20062015, and to indicate which ratios are more influential than others on share prices. The research population which consisted of (4 companies) is taken from insurance companies listed in the Iraqi Stock Exchange Market. The research sample consisted of one of these companies, Its" Iraqi International insurance Company representing 25\% of the research population.

In the statistical analysis a multiple regression model was used to determine the relationship between the independent and the dependent variables and the results of this study showed that there is a statistically significant relationship and effect between some financial ratios and the share price. The study gave a general background on the financial markets and the Iraqi Stock Exchange Market in particular. What characterizes this study from previous ones is demonstrating the effect of the financial ratios on the share price in the Iraqi setting for insurance companies listed in the Iraqi Stock Exchange using the multiple regression method.
\end{abstract}

\section{Keywords}

financial ratios; share price; financial markets; Iraqi stock market; multiple regression

\section{JEL Classification}

C22; G15

\section{Introduction}

The financial ratios are considered to be one of the most useful financial indicators in the field of financial analysis and the overall performance of the company, which investors seek to know. Financial markets play a role in the economic activity in terms of their functions both in the developed and the developing countries. Investors always try to avoid risk in their investments, especially investing in insurance companies, so that they can also transfer part of these investments into existing funds while at the same time ensuring the greatest possible return. Financial ratios are seen to be of significance to shareholders, potential investors in equities, stock exchange analysts and investment banks. Shareholders and investors are interested in knowing the impact of the company's performance on the income generated from their investments in the shares of insurance companies. Therefore, the financial ratios are very important to the management of the company in term of share prices in financial markets, especially as 
the primary objective of financial management is to maximize the wealth of shareholders by maximizing the market value of the share.

The study is consisted of the following parts:

The first part: Methodology of research and some previous studies

\section{Research Methodology}

The research methodology is as follows:

\section{Research problem}

The problem of the research is represented in the following questions:

1. Do the financial ratios of insurance companies work in measuring the overall performance of the company which the investors seek to know?

2. What is the effect of the financial ratios published in the financial statements on the share price of insurance companies in the Iraqi Stock Exchange Market?

3. What is the effect of these ratios on the shares' prices of insurance companies in the Iraqi Stock Exchange Market?

\section{Research Hypotheses}

The research hypotheses are as follows:

1. There is no significant correlation between the financial ratios and the share price of Iraqi International insurance company listed in the Iraqi Stock Exchange Market.

2. There is no statistically significant effect between the financial ratios on the share price of Iraqi International insurance company listed in the Iraqi Stock Exchange Marketj

\section{Research Objectives}

The objectives of the research are to:

1. Identify the dimensions of the financial ratios' analysis, advantages and how to utilize it in determining the share price of insurance companies.

2. Identify the implications of the financial ratios' analysis on the quality of information published in the financial statements of insurance companies whose shares are traded in the Iraqi Stock Exchange Market.

3. Develop a quantitative model using multiple regression analysis in determining share price based on financial ratios.

\section{Research significance}

The importance of the research is that it discusses the dimensions of the financial ratios' analysis of the insurance companies whose shares are traded in the Iraqi Stock Exchange Market as well as their effect on the share price using regression analysis method because the financial market's activity in Iraq reflects the economic activity of companies, especially insurance companies, so we find that there are factors impacting the share prices including the financial ratios which this study explores its effect on the share price using a quantitative statistical method which is the multiple regression analysis.

\section{Research population and sample}

The research population consists of the insurance companies listed in the Iraqi Stock Exchange Market, totaling (4) companies and the sample of the research is one 
company of these companies, it`s Iraqi International insurance company which represent $25 \%$ of the research population.

\section{Time period and location of the research}

Time period: The time range of the research is determined by reference to a time series of financial ratios and the company's share price for the research sample from 2006 to 2015.

Locational boundaries: Iraqi Stock Exchange Market

\section{Some previous studies \\ First: Arabic studies}

1. The study of Yunus 1995 (the effect of issuing shares on the returns of shares in the Amman Financial Market). The study aimed at verifying the effect of issuing shares on their returns by calculating the extraordinary return resulting from announcing the issuance. The researcher studied (5) banks, (3) service companies and (13) industrial companies. The study included a cross sectional analysis for testing without the independent factors. The test results showed that they were not significant determinants. The test also included the absence of unusual behavior during the underwriting period, in addition to giving a background to the financial markets, the system and growth of the volume of equity issues in Jordan.

2. The study of Badri and Al-Khoury, 1997 (Study of Stock Movements in the Amman Financial Market Using the Econometric Models). The study aimed at identifying the movements of shares in the Amman Financial Market using standard models based on the analysis of quarterly information between 1978-1994. The standard estimates of the models presented in this study showed that there is a statistically significant relationship between movements in share prices and some macroeconomic variables, without the possibility of relying on this information in making investment decisions.

3. The Hussein study titled (Securities and their markets with reference to the Iraqi Stock Exchange Market- Theoretical Framing) aimed at explaining the role of the stock market as the main driving force for economic growth as economic progress is closely linked to the existence of a thriving and developed stock exchange market. In addition to increasing securities and their diversity leads to increased public interest, from many categories such as owners of surplus funds from savers who wish to invest their money in the market for a long term in various possible ways of issuance and exchange.

\section{Second: Foreign Studies}

1. The study of Filion \& Boyer 2004 (Common and fundamental factors in stock returns of Canadian oil and gas companies). The study aimed at identifying how the share in the industrial sector was affected by a number of factors for the sector and the market returns for this sector. The study concluded that the returns of this sector are corresponding positively with the market returns and oil prices and that it is inversely correlated with interest rates as well as Canadian exchange rates against the US dollar. 2. The study of Shin, Chin, 1997 " Open-Market stock repurchase announcements and revaluation of prior accounting information". It aimed at showing the extent of open market interaction with the published accounting information and its impact on share repurchase. A sample of 323 markets was used during the period from 1978 to 1992. The study concluded that the market is affected by the published accounting information. Also there is a relationship between repurchasing the shares and the market's response to the accounting information. 


\section{The theoretical framework \\ Concept of shares (equities)}

The underwritten shares (and the added ones) are formed by investors, which include their financial contributions and determine their ownership of the company. Consequently, both the declared capital and the actual capital as well as the equity capital are all terms reflecting the total value of the shares acquired by the investors. The share gives its holder a right or a share in the ownership of the company and this share is determined by the number of shares he owns to the number of the issued shares. The share is defined as a " financial document issued by a shareholding company with a nominal fixed value, which is the (par value) ensuring equal rights and obligations for its owners and is offered to the public through underwriting in the essential market (Primary market) and it is allowed to be traded in secondary markets (Al-Jarjawi, 2008).

\section{Securities' markets}

These are financial institutions dealing with investing in securities in terms of issuance and exchange in which the buying and selling of financial securities such as shares and bonds are conducted. The operations of these markets entail returns and risks. Hence the financial market is the mechanism through which purchasing, sharing and exchange of financial assets which include (shares, bonds and currencies) are carried out (AlAmiri, 574: 2013).

(Al-Rubaie, 2009:7) points out to the market as being the place where investors meet and transactions of securities in terms of selling and purchasing are done. These transactions form one of the channels through which money flows into between individuals, institutions and different sectors which helps in mobilizing, developing, and preparing them for investment fields.

\section{Iraqi Stock Exchange Market}

Iraqi Stock Exchange Market or the so-called Baghdad Stock Exchange (Bursa in Arabic), was established in 1991 to meet the foreign requirements or conditions during the period when the international sanctions were imposed and as one of the structural transformation measures in the Iraqi economy towards the private sector. As a government market run by the Iraqi Ministry of Finance, it absorbed during the period of 1992 and 2003 about 113 Iraqi companies of private and mixed companies with an annual circulation of more than 17 million dollars. In line with the new situation in Iraq, which emerged after 2003 with focus on the role of the private sector, removing economic restrictions and opening to the outside world, the Baghdad Stock Exchange market has been canceled and the Iraqi Stock Exchange Market was established under the name the Iraqi Securities Commission, similar to the American Securities Commission under the law 74 for the year 2004. In accordance with this trend two institutions have been established which are the Iraqi Stock Exchange Market and the Iraqi Securities Commission, which since 2005 became an independent body and became the only exchange market in Iraq (Al-Hamdani, 2013: 1)

\section{Objectives of the Iraqi Stock Exchange}

The Iraqi stock market aims to achieve the following objectives (Al-Rubaie, previous source: 7):

1. Organizing its members and preserving the recognized criteria of companies in a way that suits investors and enhance investors' confidence in the market.

2. Organizing transactions for members in the services related to the bonds as well as the operational procedures and determining the rights and obligations of the relevant parties and means to protect their legal interests.

3. Enhancing investors' interests in efficient, reliable, competitive, transparent and truthful markets.

4. Collecting, analyzing and publishing necessary statistics as well as information to achieve the objectives stipulated in the Law of Securities Market. 
5. Establishing and supporting contacts with Arabian and international financial markets which can constructively contribute in the development of the stock markets and other licensed markets.

\section{The concept of financial ratios}

The financial ratios are logical relationships between certain elements in the financial statements. Many of them can be calculated by linking a given element to another one, taking into account a logical relationship between the two elements which the ratio is intended to be calculate for both of them. These two elements may appear in the same list or may appear between two different lists (Albadawi and Shahatah, 2003:202). The financial ratios are viewed to be better than the comparison method between the elements of the financial statements due to the existence of defect in the comparison of the aggregates and the details of the financial statements' elements where growth or decrease in the business activity of the company is not taken into account. Hence with calculating the financial ratios of the financial statements' elements and comparing them with their counterparts of the previous years for the same company or others, this defect can be overcome. Thus, the financial analyst can produce more accurate results when making comparisons in the analytical procedures' methods (Naim, 2008: 63).

\section{Objectives of Financial Ratios}

The most important financial ratios' objectives can be explained as follows:

1. Understanding given data in the financial statements in order to assist the management in making various decisions as the financial indicators resulting from financial analysis reveal the strengths and shortcomings in the financial position of the firm. In addition to that using these indicators enable the company of examining its previous achievements. Accordingly demonstrating their commitment to the financial policies.

2. Reducing the large volume of the financial statements to a small and useful number of clearly defined financial indicators (Al-Jerjawi : 2008, 58).

\section{Types of financial ratios}

First: Liquidity Ratios

These ratios can help in identifying the ability of the economic unit to meet its shortterm financial obligations (Polis, 2009: 45), including:

1. Current ratio $=$ current assets $/$ current liabilities

2. Rapid Liquidity ratio $=$ (current assets - inventory $) /$ current liabilities

Second: profitability ratios

The profitability ratios reflect the overall performance of the company as the profitability ratios unify the impact of most management decisions. It examines the company's ability to generate profits from sales, assets and property rights, which is the measure of the effectiveness of management policies for the investment, financing and operating companies. (Al-Amry, 2013: 88)

1. Net profit margin $=$ net profit of the current operations $/$ net sales

2. Return on total assets $=$ net profit after taxes $/$ total assets

3 . Return on equity (property right) $=$ net profit after taxes $/$ total equity rights.

Third: the ratio of indebtedness

In general, indebtedness ratios focus on measuring the ability of a company to service long-term debts and repay them when it is due. Beside that when the date of those debts is due, the firm must be able to repay those debts from its own funds (equity) or borrow again. Certainly the ability of the firm to get or repay long-term debts often depends on or is related to the ability of the crediting corporations to be clarified (Lotfi , 2008: 348) and it includes:

1. Ratio of current liabilities to the equity $=$ current liabilities / equity

2. Ratio of debt to equity $=$ total liabilities $/$ total equity 
Fourth: Operating and activity ratios

Based on these ratios, efficiency or activity indicators are obtained which are considered a measure of the efficiency and effectiveness of the economic unit in exploiting and managing its assets. These ratios include (Polis, 2009: 47):

The rate of total assets' trading $=$ net sales $/$ total assets

The rate of current assets' trading = net sales / current assets

The rate of net capital trading $=$ net sales / net working capital

Fifth: Market ratio (shares)

It is a set of financial ratios showing the relationship of the share's price to the profits, cash flows and the book value of the share, as well as giving investors an image of the company's past and expected positions. These ratios (relevant to the market) are viewed as the most important ratios for investors, creditors, investment banks and financial analysts as they use them to achieve their aims and objectives (Brigham \& Ehrhardt, 2005: p 454). These ratios are represented as follows:

1. Profit ratio per ordinary share $=$ net profit after interests and taxes / number of ordinary shares

2. Market value to the book value $=$ ordinary share's price in the market / book value of the ordinary share

3. Ratio of the share's price to the share's profit $=$ ordinary share's price in the market / the share's profit

4. Book value of ordinary share $=$ total value of ordinary shares / number of ordinary shares

\section{The applied side of the research}

Al-Ameen Insurance Company was incorporated in Baghdad under the incorporation certificate No. 7606 on 31/7/2000 with a capital of 150 million Iraqi dinars (ID). Its capital in 2015 was $3,410,100,000$ ID. The company aims to provide the best security coverage, most suitable and beneficiary to protect the national economy and community members as well as invest the funds accumulated for the best available investment opportunity. The company achieved a net profit in 2015 of 326,040,231 IDs. Table (1) shows the Company's share price and financial ratios for the years 2006-2015. From the table, data were analyzed to extract the following:

First: finding the multiple correlation between the dependent variable (Y) represented by the share price and the independent variables represented in the financial ratios.

In order to establish correlation between variables, the statistical analysis program (SPSS-20) was used, and the outputs shown in table (2) were obtained.

Table 1 The Share Price and Financial Ratios of the Company

\begin{tabular}{|c|c|c|c|c|c|c|c|c|}
\hline Years & $\begin{array}{l}\text { Share } \\
\text { price } \\
\text { (Dinar) } \\
(\mathrm{Y})\end{array}$ & $\begin{array}{l}\text { Current } \\
\text { ratio } \\
(\mathrm{X} 1)\end{array}$ & $\begin{array}{c}\text { Ratio } \\
\text { of } \\
\text { return } \\
\text { on } \\
\text { assets } \\
\text { (X2) }\end{array}$ & $\begin{array}{l}\text { return } \\
\text { on } \\
\text { equity } \\
\text { (X3) }\end{array}$ & $\begin{array}{c}\text { Ratio of } \\
\text { current } \\
\text { liabilities } \\
\text { to equity } \\
\text { (X4) }\end{array}$ & $\begin{array}{c}\text { Profit } \\
\text { Ratio } \\
\text { per } \\
\text { Ordinary } \\
\text { Share } \\
\text { (X5) }\end{array}$ & $\begin{array}{l}\text { Ratio } \\
\text { of } \\
\text { market } \\
\text { value } \\
\text { to book } \\
\text { value } \\
\text { (X6) }\end{array}$ & $\begin{array}{c}\text { Ratio of } \\
\text { book } \\
\text { value to } \\
\text { ordinary } \\
\text { share } \\
\text { (X7) }\end{array}$ \\
\hline 2006 & 1.500 & 2.501 & 0.073 & 0.121 & 0.650 & 0.189 & 1.200 & 1.220 \\
\hline
\end{tabular}




\begin{tabular}{|l|c|c|c|c|c|c|c|c|}
\hline 2007 & 0.950 & 3.086 & 0.084 & 0.123 & 0.475 & 0.151 & 0.910 & 0.670 \\
\hline 2008 & 1.050 & 2.108 & 0.133 & 0.178 & 0.342 & 0.182 & 1.027 & 1.220 \\
\hline 2009 & 1.100 & 2.065 & 0.064 & 0.083 & 0.302 & 0.191 & 1.011 & 1.720 \\
\hline 2010 & 1.350 & 5.257 & 0.018 & 0.022 & 0.218 & 0.198 & 1.188 & 1.690 \\
\hline 2011 & 1.220 & 9.170 & 0.053 & 0.059 & 0.114 & 0.165 & 1.019 & 1.010 \\
\hline 2012 & 1.050 & 11.269 & 0.092 & 0.100 & 0.090 & 0.121 & 1.002 & 1.006 \\
\hline 2013 & 2.000 & 10.352 & 0.173 & 0.185 & 0.071 & 0.263 & 1.805 & 1.760 \\
\hline 2014 & 1.420 & 9.971 & 0.099 & 0.109 & 0.096 & 0.143 & 1.031 & 1.140 \\
\hline 2015 & 0.770 & 8.209 & 0.074 & 0.082 & 0.120 & 0.140 & 0.560 & 0.748 \\
\hline
\end{tabular}

Source: These data have been extracted from the company's financial statements and annual studies published on the website of the stock market "http://www.isc.gov.iq" as well as field visits to the Iraqi Stock Exchange Market and the research sample's

Considering that the dependent variable represented in the share price symbol is (Y), so he independent variables are:

(X1) current ratio

(X2) rate of return on assets

(X3) return on equity (property rights)

(X4) Ratio of current liabilities to equity

(X5) Profit ratio per ordinary share

(X6) Ratio of market value to book value

(X7) Ratio of book value to ordinary share

Table 2. Coefficients of correlation between dependent and independent variables

\begin{tabular}{|l|l|l|l|l|l|l|l|l|}
\hline & Y & X1 & X2 & X3 & X4 & X5 & X6 & X7 \\
\hline $\begin{array}{l}\text { Pearson } \\
\text { Correlation }\end{array}$ & $\mathbf{1 . 0 0 0}$ & $\mathbf{. 2 6 0 0}$ & $\mathbf{. 4 2 9}$ & $\mathbf{. 3 4 1}$ & $\mathbf{. 4 8}-$ & $\mathbf{. 7 7 4}$ & $\mathbf{. 9 4 0}$ & $\mathbf{6 5 5}$ \\
& & & & & & & & \\
\hline Sig.(1-tailed) & & 0.023 & 0.026 & 0.039 & 0.016 & 0.04 & 0.00 & 0.020 \\
\hline N & 10 & 10 & 10 & 10 & 10 & 10 & 10 & 10 \\
\hline
\end{tabular}

** The correlation is statistically significant at a level of 0.05 .

Source: outputs of the Statistical Analysis Program (SPSS-20)

From Table 2 above we conclude that:

1. The correlation between the variable $(\mathrm{Y})$ represented by the share's price and the trading ratio (X1) is a weak positive relationship (0.260) and the value of sig $=$ 0.023 , which is less than the level significance of 0.05 . This is because of the insurance sector aiming at having large liquidity for the companies to pay their dues during the process of compensation. 
2. The correlation between the share's price (Y) and the return on assets (X2) is positive $(0.42)$ and sig $=(0.010)$, which is below the level of significance at 0.05 .

3. The correlation between the share's price $(\mathrm{Y})$ and the return on equity $(\mathrm{X} 3)$ was positive reaching to $(0.34)$ and $\operatorname{sig}=(0.039)$, which is below the significance level of 0.05 .

4. The correlation between the share's price $(\mathrm{Y})$ and the ratio of current liabilities to equity (X4) has a negative inverse relationship of $(-0.48)$ and the value of sig $=0.016$ which is less than the significance level $(0.05)$.

5. The correlation between the share's price $(\mathrm{Y})$ and the profit per share ratio (X5) was positive (0.774) and the value of $\mathrm{sig}=0.04$ was below the significance level of 0.05 .

6. The correlation between the share's price $(\mathrm{Y})$ and the ratio of market value to book value (X6) was positive (0.94) and sig $=0.00$, which is below the significance level of 0.05 .

7. The correlation between the share price $(\mathrm{Y})$ and the ratio of book value to the ordinary share was positive $(0.65)$ and $\mathrm{sig}=0.020$, which is below the significance level of 0.05 .

From what has been presented it is clear that there is a significant correlation between the share's price and the financial ratios and we can reject the null hypothesis H0: "there is no significant correlation between the financial ratios and share's price of insurance companies listed in the Iraqi Stock Exchange Market". We accept the alternative hypothesis H1.

Second: Estimation of the Multiple Regression Model: The multiple regression model was estimated using the statistical method shown in the following table:

Table 3: Summary of the relationship model Example of figure

\begin{tabular}{|c|c|c|c|c|c|c|c|c|c|c|}
\hline \multicolumn{11}{|c|}{ Model Summary ${ }^{b}$} \\
\hline \multirow[t]{2}{*}{ Model } & \multirow[t]{2}{*}{$\mathrm{R}$} & \multirow{2}{*}{$\begin{array}{c}\mathrm{R} \\
\text { Square }\end{array}$} & \multirow{2}{*}{$\begin{array}{c}\text { Adjusted } \\
\mathrm{R} \\
\text { Square }\end{array}$} & \multirow{2}{*}{$\begin{array}{c}\text { Std. } \\
\text { Error of } \\
\text { the } \\
\text { Estimate }\end{array}$} & \multicolumn{5}{|c|}{ Change Statistics } & \multirow{2}{*}{$\begin{array}{l}\text { Durbin- } \\
\text { Watson }\end{array}$} \\
\hline & & & & & $\begin{array}{c}\mathrm{R} \\
\text { Square } \\
\text { Change }\end{array}$ & $\begin{array}{c}\mathrm{F} \\
\text { Change }\end{array}$ & df1 & df2 & $\begin{array}{l}\text { Sig. F } \\
\text { Change }\end{array}$ & \\
\hline 1 & $.970^{\mathrm{a}}$ & .941 & .736 & .178587 & .941 & 4.583 & 7 & 2 & .191 & 2.170 \\
\hline
\end{tabular}

a. Predictors: (Constant), X7, X3, X1, X5, X4, X6, X2

b. Dependent Variable: y

Source: outputs of the Statistical Analysis Program (SPSS-20)

Table 3 shows that the coefficient of determination (R2) demonstrated the high explanatory power of the independent variables of the financial ratios on the dependent variable (the share's price) as it pointed out that $94 \%$ of the changes in the dependent variable are explained by the independent variables, with the remaining $(6 \%)$ belongs to other explanatory variables not included in the model, while value of $(\mathrm{F})=4.538$.

As for the Durbin-Watson test, its value of (2.170) indicated that there was no problem of self-correlation between residues in the model.

The result of regression analysis is illustrated in the following table: 
Table 4: Analysis of regression variance

\begin{tabular}{|c|c|c|c|c|c|c|}
\hline \multicolumn{7}{|c|}{ ANOVA $^{a}$} \\
\hline \multicolumn{2}{|c|}{ Model } & Sum of & $\mathrm{df}$ & Mean Square & $\mathrm{F}$ & Sig. \\
\hline & Regression & 1.023 & 7 & .146 & 4.583 & $.000^{\mathrm{b}}$ \\
\hline 1 & Residual & .064 & 2 & .032 & & \\
\hline & Total & 1.087 & 9 & & & \\
\hline
\end{tabular}

a. Dependent Variable: y

b. Predictors: (Constant), X7, X3, X1, X5, X4, X6, X2

Source: Outputs of the (Spss-20)

Table 4 shows that the calculated value of $(F)$ which is (4.583) with a degree of numerator freedom (7) and a denominator degree of 2 and at a significance level (0.000).

Thus, we obtained the coefficients of the regression equation line and standard deviations which can be shown in the table below:

Table 5: Coefficients of the regression equation and its standard deviations for the effect relationship between the financial ratios on the share's price (Y)

Coefficients $^{\mathrm{a}}$

\begin{tabular}{|c|c|c|c|c|c|}
\hline \multirow[t]{2}{*}{ Model } & \multicolumn{2}{|c|}{$\begin{array}{c}\text { Unstandardized } \\
\text { Coefficients }\end{array}$} & \multirow{2}{*}{$\begin{array}{l}\text { Standardized } \\
\text { Coefficients } \\
\text { Beta }\end{array}$} & \multirow[t]{2}{*}{$\mathrm{T}$} & \multirow[t]{2}{*}{ Sig. } \\
\hline & B & Std. Error & & & \\
\hline \multirow{7}{*}{. } & $-.893-$ & .910 & & $-.981-$ & .025 \\
\hline & .90 & .078 & .981 & 1.153 & .016 \\
\hline & 3.507 & .306 & $-1.294-$ & $-.358-$ & .014 \\
\hline & 8.975 & .784 & 1.287 & .362 & .152 \\
\hline & $-.60-$ & .596 & .338 & .378 & .0242 \\
\hline & 3.341 & .650 & .387 & .719 & .0547 \\
\hline & .342 & .768 & .306 & .445 & .700 \\
\hline $\mathrm{X} 7$ & .335 & .449 & .378 & .745 & .0534 \\
\hline
\end{tabular}

a. Dependent Variable: $y$

Source: Outputs of the program SPSS-20

Table 5 shows that the values of:
(a) $=(0.893)$
(b1) $=(0.90)$
(b2) $=3.507$
(b3) $=8.975$
(b4) $=(-0.60)$
(b5) $=3.341$
$(\mathrm{b} 6)=0.342$
$(\mathrm{b} 6)=0.335$

And The regression equation is: 


$$
\begin{gathered}
\hat{\mathrm{Y}}=(-0.893)_{(\mathrm{t}=0.981)}+(0.90) \mathrm{X} 1_{(\mathrm{t}=1.153)}+3.507 \mathrm{X} 2_{(\mathrm{t}=0.362)}+8.975 \mathrm{X} 3_{(\mathrm{t}=0.362)}+(- \\
0.60) \mathrm{X} 4_{(\mathrm{t}=0.378)}+3.341_{\mathrm{X}} 5_{(\mathrm{t}=0.719)}+0.342_{\mathrm{X}} 6_{(\mathrm{t}=0.445)}+0.335 \mathrm{X} 7_{(\mathrm{t}=0.745)} \\
\mathrm{R}^{2}=\% 94 \overline{\boldsymbol{R}}^{2}=73 \% \mathrm{~F}=4.583 \mathrm{DW}=2.170
\end{gathered}
$$

From the above equation we conclude the following:

1. The equation indicates that there is a positive effect correlation between the variable (X1) represented by the trading rate on the share's price of the insurance company with the value of (0.90), which means increasing this percentage leads to the increase in the share's price in the stock market because the success of the insurance companies is with having a high liquidity ratio for the purpose of compensation and payment of dues.

2. There is a positive effect correlation between the variable (X2) represented by the rate of return on assets on the share's price amounting to (+3507), i.e. the increase of this ratio leads to an increase in the share's price in the stock market.

3. There is a positive effect correlation between the variable (X3) represented by the ratio of return on equity to the share's price of 8.975 , which means that the increase in this percentage leads to an increase in the share's price in the stock market.

4. There is an inverse effect relationship between the variable (X4) represented by the ratio of current liabilities to equity on the share's price with the value of $(-0.60)$, i.e. an increase in this ratio leads to a decrease in the share's price in the stock market.

5. There is a positive effect correlation between the variable (X5) represented by the percentage of profit per every ordinary share on the share's price by 3.341 , i.e. increasing this percentage leads to an increase in the share price in the stock market.

6. There is a positive effect correlation between (X6) represented in the ratio of the market value to the book value of the share price by the amount of 0.342 , i.e. an increase in this percentage leads to an increase in the share price in the stock market.

7. There is a positive effect correlation between (X7), which is the ratio of the book value of the ordinary share to the share price of 0.335 , i.e. an increase in this percentage leads to an increase in the share price on the stock market.

Based on what have been stated above we can reject the second null hypothesis : (H0), which states that "there is no statistically significant effect between the financial ratios on the share's price of insurance companies listed in the Iraqi Stock Exchange Market" and accept the alternative hypothesis (H1).

\section{Conclusions and recommendations}

\section{Conclusions}

1. The ratio of current liabilities to equity (property rights) is inversely affecting the share's price of Insurance companies in the stock market i.e. increasing this ratio leads to a decrease in the share's price.

2. The ratios (trading and return on assets, return on equity, profit per ordinary share, market value to book value, book value per ordinary share) positively affect the share's price of the insurance companies, i.e. their increase results in increasing the share's price in the stock market.

3. When analyzing the financial statements of the insurance companies listed in the Iraqi Stock Exchange Market, a large number of financial ratios can be used which can 
be divided into groups and each group we will examine a study a specific phenomenon. This will depend on the purpose of the process of the financial analysis.

4 - Knowing the financial ratios by investors leads to knowing the movement of the share price's trend during a given period.

\section{Recommendations}

1. Paying attention to the process of financial analysis because of its active role in stating the financial position of enterprises, as well as its role in the rationalization of investment decisions.

2. The Iraqi Stock Exchange Market should necessarily require the listed companies to prepare their financial statements in accordance with international accounting standards with a view to standardizing the procedures and rules adopted in the preparation of these lists in order to help investors to make comparisons between the performance of companies in the insurance sector and other sectors when making the investment decision.

3. The importance of paying attention to the accuracy of the data contained in the financial statements and ensuring transparency in disclosing its contents.

4. The need for the Iraqi Stock Exchange Market to require the listed companies to prepare the list of the cash flows in addition to both balance sheet as well as the profits and losses due to their importance at the time of taking Investment decisions, as this list was not available in a number of companies.

\section{References}

Al- Jerjawi, Halima Khalil, (2008), The Role of Financial Analysis for Financial Information Published in Financial Statements for Forecasting Shares' Prices, Master Thesis in Accounting and Finance, Gaza, Islamic University.

Al- Amiri, Muhammad Ali Ibrahim, (2013), The Modern Financial Administration, First Edition, Amman, Alwael house for Publishing.

Al-Badawi, Mansour Ahmad and Shahatah, Al-Said Shahatah, (2003), Modern Trends in Auditing, Alexandria, Al-Dar Al-Jamaa'ia, (Univesity House).

Brigham, Eugene F. \& Ehrhardt, Michael C., (2005), Financial Management, 11 edition, USA

Filion, Boyer, M, (2004), Common and fundamental factors in refures of Canadian oil and gas companies

Naim, Lewis, (2013), The Importance of Using Analytical Procedures in Auditing Phases, Applied Study in the Public Economic Corporation - Jijle for Phlin, Master Thesis in Commercial Sciences, Department of Financial Accounting, Branch of Auditing, Algeria, University of Muhammad Khudaira Biskra, Faculty of Economics, Business and Information Sciences.

Polis, Hind Yusif, (2009), The Use of Financial Ratios as a Benchmark for Accessing an Acceptable Tax Base, High Diploma Dissertation Equivalent to Master's degree, Higher Institute of Accounting and Financial Studies, University of Baghdad.

Lutfi, Amin Alsaid Ahmed, (2007), Modern Developments in Auditing, Alexandria, Dar Al-Jamaa'ia.

Al-Rubaie, Falah Khalaf, (2009, June 26) Ways to Upgrade the Iraqi Stock Exchange Market, $A l$ - Sabah newspaper.

Al-Hamdani, Awda Naji, (2013, March 11), The Securities Market and Challenges in Meeting the Growing Financing Needs, Al-Mada Newspaper, Issue 2747.

Badri, Sabah, Khoury, Ratab, (1997), Studying Stocks' Movements in the Amman Financial Market using Standard Models, Journal of Dirasat,Vol 24, No.1, Amman, Jordan. 
Al-Hussein, Mayson Ali, (2013), Securities and their Markets with Reference to the Iraqi Stock Exchange Market, Theoretical Framing, Journal of Babel University for Humanities, Volume 21, No. 1, Iraq.

Shin, liu, Chin, Jennifer, Open-Market stock repurchase announcements and revaluation of prior accounting information, The accounting review, Vol.25, no. 99

Yunus, Bahjat, (1995), The Effect of Shares' Issuance's on Shares' Returns in the Amman Financial Market, Unpublished Master Thesis, University of Jordan, Amman, Jordan.

http://www.isc.gov.iq 